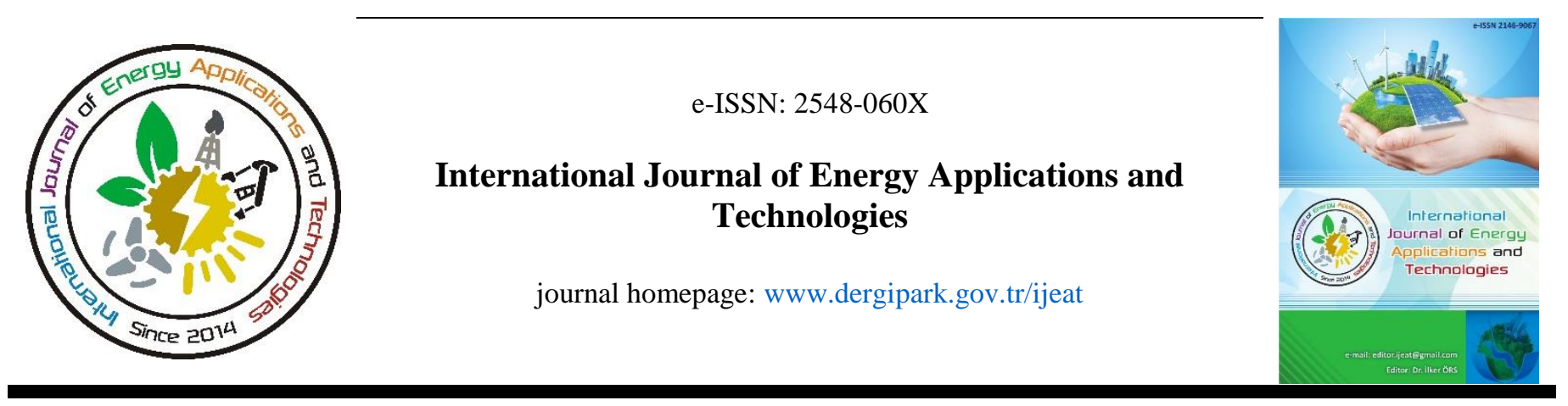

Review Article

\title{
Renewable energy politics from the perspectives sustainability: Economy, ecology and energy
}

\author{
Fatih Şeker ${ }^{1}$, Çağrı Avan²*, Bahattin Aydınlı ${ }^{3}$ \\ ${ }^{1}$ Küçükçekmece Secondary School, Ministry of Education, Istanbul, Turkey \\ ${ }^{2}$ Science Educatioun, Science Institute, Kastamonu University, Kastamonu Turkey \\ ${ }^{3}$ Preschool Education, Faculty of Education, Kastamonu University, Kastamonu, Turkey
}

\section{ARTICLE INFO \\ * Corresponding author cagriavan@gmail.com \\ Received January 27, 2020 \\ Accepted April 23, 2020 \\ Published by Editorial Board Members of IJEAT \\ C) This article is distributed by Turk Journal Park System under the CC 4.0 terms and conditions.}

doi: 10.31593/ijeat.680639

\begin{abstract}
Many new concepts have been constructed by associating many familiar concepts such as tourism, energy, agriculture and development to the term of sustainability. Some of them are; sustainable development, sustainable agriculture and sustainable tourism etc. Undoubtedly, sustainability is mentioned in many areas such as media, politics, economics and academia. This concept is tried to be gained through the information and practices provided about sustainability to the individuals who make up the society. It is known that sustainability in science education is not evaluated with a holistic approach from the perspective of economy, ecology and energy. If it is assumed that individuals have not theoretical background and culture about sustainability, there can be thought that they will have problem for sustainable lifestyle. Therefore, it can be said that theoretical and practical studies which will help individuals are important in order to a more livable World. The purpose of this study is to construct broad a conceptual framework upon renewable energy policies from the sustainability perspective by linking the terms of economy, ecology and energy known in the literature as 3E. In the method of this research, firstly sustainability is examined from a holistic approach and was developed a model. Then starting from sustainability, socio-scientific issues, production, wastes, ecology, sociology, feminism, cultures, developmental differences, energy production, energy storage and transportation, the renewable ones, photosynthesis, biomass and pyrolysis are connected and interrelated in holistic manner by considering chemistry and politics. In the result of the research, it is arisen that conservative and elder women who is the ability to be happy while consuming less which must be followed and obeyed. By this way, new insights can be obtained and deduced for better inhabitable world peacefully.
\end{abstract}

Keywords: Science education; Sustainability; Energy; Environment; Wastes; Economy

\section{Introduction}

Nowadays, the whole world has been fighting against anarchy and terrorism, starvation and poverty and environmental disasters that have become chronic problems. While it is thought that such problems will disappear with the development of humanity, technology and modern management systems, unfortunately problems have started to become even more chronic [1]. When looking at biotic and abiotic elements of nature, it is understood that the most important element that interferes with nature is human. Considering plants, animals, lifeless objects, and their continuity, it is understood that there is no need of human mind to sustain life. It is deeply perceived that mind and human mind exist for other achievements [2]. This has caused an irresistible feeling of curiosity and therefore, a sense of research. As a result, humanity has become incompatible with its environment while making new 
discoveries and inventions. Although the damage caused by this incompatibleness is tried to be explained in various ways, human activities are gaining speed [3]. In general, there are two perspectives in the relationship of man with the environment; these are expressed in English as ecocentric and anthropocentric. The representation of the ecosystem approach between ecocentric and anthropocentric is given in Figure 1.
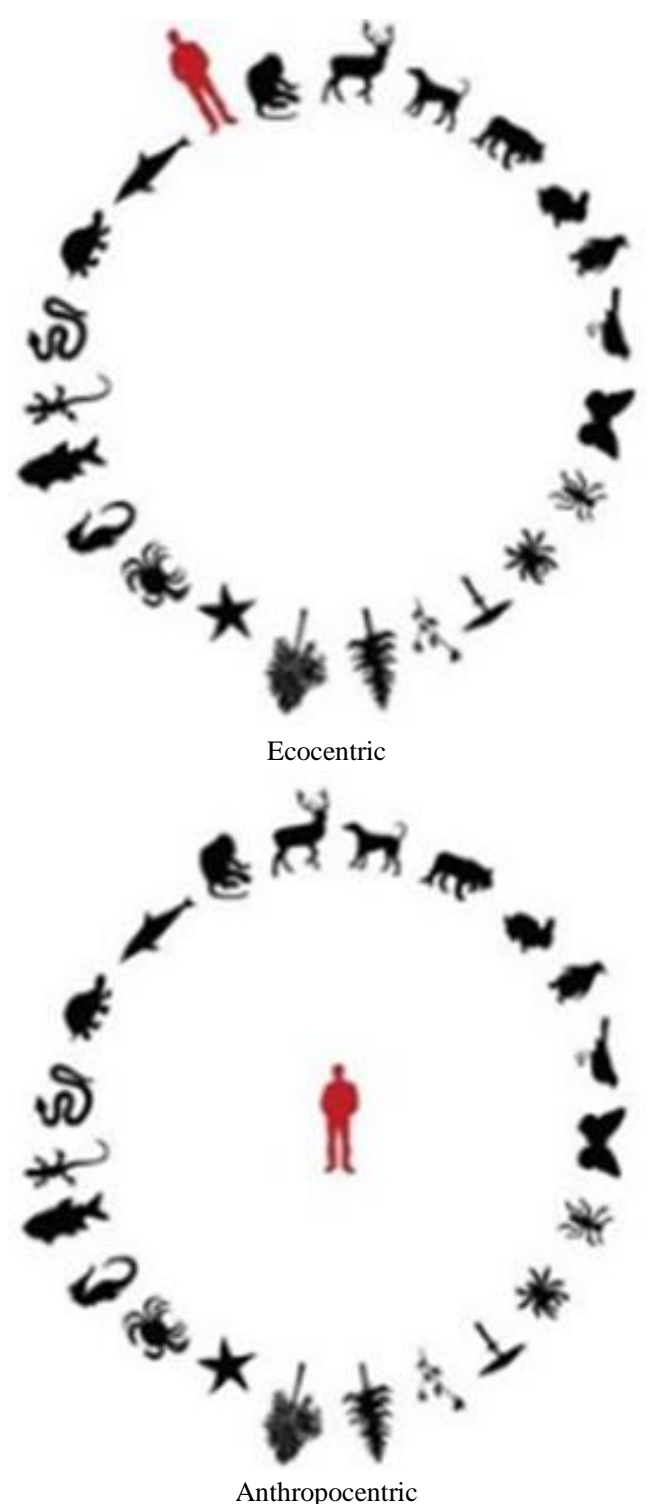

Fig. 1. Ecosystem approach between Ecocentric and Anthropocentric

The "Ecocentric" approach is environmentally based and basically is based on the view of the environment to have the same rights as people. The "Anthropocentric" approach is human-oriented and is based on the perspective that various destructions can be made in the environment for the benefit of humanity $[4,5]$. As a result of adopting these approaches, unprecedented complex problems have arisen. Each of these problems causes numerous systematic dysfunctions in ecological, economic and social dimensions without a simple cause or solution [6]. These approaches are not sufficient to prevent the world from getting worse and to turn the negativities into a positive situation, and a new concept is sought. Today, the definition of ecological citizenship, which also includes political power, comes to the fore with the definition of sustainability and sustainable development, which is tried to be valid all over the world. The need for ecological citizenship education on issues that concern our world and our universe has made the importance of sustainable development increasingly clear. The concept of sustainable development has several dimensions, which are mainly ecology, economy and energy, but also include many social, industrial and political concepts [7]. Sustainable development, which has an increasing importance at the global level, is accepted as the solution of the problems on our planet $[8,9]$. Sustainability and sustainable development is attracting global attention and striving to understand the interaction between nature and society [10]. Science education improves the relationship between nature and society by taking into consideration the concerns and priorities of the problems at the regional and global level. By nature, issues such as management of resources in science education, biodiversity, energy and ecology are associated with sustainable development. Therefore, sustainable development continues to be included in science education increasingly [11]. Sustainability and science education are dynamic structures, and extensive discussions continue between the two and continue their development in two concepts [12]. Science education is one of the main elements that support sustainable development. Increasing energy, economy and ecological problems should be supported in order for individuals to be knowledgeable and conscious citizens about these issues [13]. It is known that sustainability in science education is not evaluated with a holistic approach from the perspective of economy, ecology and energy. If it is assumed that individuals have not theoretical background and culture about sustainability, there can be thought that they will have problem for sustainable lifestyle. Therefore, it can be said that theoretical and practical studies which will help individuals are important in order to a more livable World.

\subsection{Purpose of the research}

The purpose of this study is to construct broad a conceptual framework upon renewable energy policies from the sustainability perspective by linking the terms of economy, ecology and energy known in the literature as 3E. In accordance with the purpose of the research, answers to the following questions were sought:

1) Can sustainability and sustainable development be successful without a holistic approach?

2) How can renewable energy policies; economy, ecology and energy concepts be related to each other from a sustainability perspective? 


\section{Method}

In the method of the research, primarily sustainable development is emphasized and a model related to sustainable development is designed. The study focuses on the second concept, "sustainable development". Thus, starting from the concept of sustainability, which is very general in this study, a conceptual theme was obtained by trying to establish a connection between knitting and weft threads between pyrolysis, which is a special recycling technology. In addition, starting from the very general concept of sustainability, a conceptual theme was obtained by trying to establish a connection between knitting and weft threads between pyrolysis, a special recycling technology. In addition, starting from sustainability, socio-scientific issues, production, wastes, ecology, sociology, feminism, cultures, developmental differences, energy production, energy storage and transportation, the renewable ones, photosynthesis, biomass and pyrolysis are connected and interrelated in holistic manner by considering chemistry and politics. The article; it is limited to sustainable development and the variables mentioned above.

\section{Research Findings and Discussion}

\subsection{Sustainability}

Today, the concept of sustainability is among popular topics in media, politics, economics and academia. While maintaining the importance of sustainable development, it was buzzword in the mouth of people in all environments. There are several definitions for sustainability and sustainable development. Sustainability means continuity with its shortest version. If a better definition is made, it can be defined as ongoing transactions without harming any situation. It can be said that it is a state of durability [14]. Maybe something also little but the continuous one is more acceptable. A constantly flowing small fountain may be larger than a small lake that does not feed on any source. It is understood from here that it is acceptable for something to be continuous although it is also little. In an opposite situation, it will be difficult to use something efficiently as there will be imbalance. Here, renew is considered essential.

In general, it is combined with other concepts such as sustainability and development and new concepts emerge as a result of the intersection of concepts. The most famous of these is "sustainable development". Sustainable development is a method that attempts to progress in economic growth and social welfare as well as environmental protection and the quality of life of all humanity [15].

In fact, it should be mentioned briefly about sustainable development and entrepreneurship. Perhaps the way of sustainable development is through the spirit of entrepreneurship. Entrepreneurship is creating new values rather than money and profit. In this way, through sustainable development, success can be achieved in combating hunger and poverty and environmental problems can be prevented. Sustainable development can be defined as meeting the needs and efficient use of natural resources by increasing the awareness and awareness levels of current and future generations on these issues. A more comprehensive definition was made by Şeker and Aydınlı, (2016) [16]. According to definition: Sustainable development is the increasing production of new resources by using the available ones in an efficient and productive way so as to ensure that a system or an entity proceeds without being interrupted; the maintenance of natural balance while realizing this function; and a term which directs the system that supports the improvement and reinforcement of generational and intergenerational life standards, social solidarity and the increase of equality of opportunity.

As mentioned briefly above, "Sustainability" is constantly associated with new concepts and new areas of work are emerging. Tourism, energy and education come at the beginning of these. Sustainability concept and sustainable development are associated with various concepts and subject areas bearing the concept of sustainability are becoming popular in many areas of society, from politics to academia and from media to the economy.

Now, it is known that sustainability is a concept that is available all over the world, from the mothers' child in the womb to death, from the garden in front of our house to a country, wherever and whenever you go. However, the frequent use of this subject in daily life and its inclusion in education programs brings inevitable confusion or misunderstandings. By solving these misunderstandings, a theoretical solution can be found to integrate these topics into the science education curriculum. In addition, this concept confronts us as a socio-scientific task as it covers natural and humanities. Therefore, the inclusion of sustainable development in social science programs in addition to science education programs is on the agenda [11, 17]. In fact, the best method would be to address these issues with a holistic approach. The concept of sustainability is based on the relationships between many scientists such as energy, entropy, economy, sociology, ecology, citizenship and entrepreneurship.

A simple conceptual framework on sustainable development is given in "Figure 2". Human life is not just a material world. Human beings intellectually, idealistically and spiritually have acquired the universe, further heaven and hell as a place, a living space, briefly a "place of life in the world". Therefore, the area of influence of human beings is many times more than the area they live in.

In natural technologies, for example, in photosynthesis, production takes place at low temperatures and with specific enzymes, and no other product is released. As a result, wastes that are formed turn into original elements, simple 
molecules with low temperature and special mechanisms. In human technologies, production takes place at high temperatures and with conventional catalysts, and due to the entropy factor, all inputs cannot be completely transformed into desired products. Since these by-products and wastes do not return to their original ways, natural pollution starts from this point. Thus, permanent wastes arise due to human activities. With new technologies, this situation may be eliminated but today, low temperature production is not possible as in photosynthesis [18, 19].

The concept of sustainable can be demonstrated simply by the formula $\mathrm{I}=\mathrm{P}+\mathrm{W}$. Here they input as the sum of human and natural resources I, Indicator of human life in the world $\mathrm{P}$ and wastes generated as a result of life are shown with $\mathrm{W}$. The chart on sustainability and sustainable development covering this formula is shown in Figure 2.

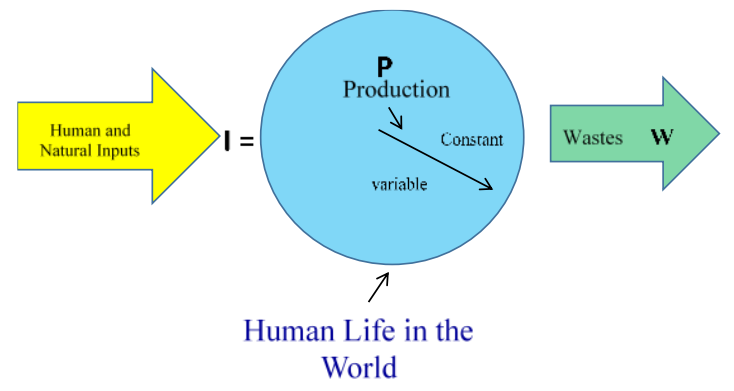

Fig. 2. Chart on sustainability and sustainable development

If human activity in the world, that is $\mathrm{P}$ is constant, then "sustainability" emerges. However, with the number of people at the same time and developing technologies, the diversity and excess of production has brought the situation from sustainability to sustainable growth or sustainable development. If $\mathrm{P}$ is variable and there is a linear relationship between $\mathrm{I}$ and $\mathrm{W}$; in this case, when human activities increase, either inputs should be increased $\mathrm{I}(\uparrow)=\mathrm{P}(\uparrow)+\mathrm{W}$ (constant) or waste should be reduced, I $=\mathrm{P}(\uparrow)+\mathrm{W}(\downarrow)$. In the other possibility, either the increase in inputs should be greater than the increase in waste $\mathrm{I}(\uparrow \uparrow)=\mathrm{P}(\uparrow)+\mathrm{W}(\uparrow)$ or both must be reduced and the reduction in waste must be greater than the reduction in inputs, $\mathrm{I}(\downarrow)=\mathrm{P}(\uparrow)+\mathrm{W}(\downarrow \downarrow)$. It may be best to call the most recent state of these events "sustainable development". Otherwise, the Earth can reach the form of a dumpster and crescent, and this can be a disaster for living things. In other words, in the first, an increase in production is tried to be achieved by using resources inefficiently and wastes are increasing. In the second, the resources are reduced efficiently by using resources. In both cases, an increase in total human activities can be observed. But only the second is a sustainable situation. In this case, there is no difference between sustainability and sustainable development. Sustainability and sustainable development have been equal.

The term sustainability is used all over the world and its
English is "sustainability". People who speak different languages use different words to meet the word sustainability. No one can be sure that all of these words mean the same thing or perceive the same. Also, the word sustainability does not provide an understanding of the same phenomenon all over the world. The understanding of this word can vary naturally or regionally depending on changing conditions in different countries, continents, unions, pact, and even in the northern and southern hemispheres [20]. Perhaps for the countries like the USA, some European countries, some countries in the Middle East, Japan and South Korea, it means protecting luxury life and going further, while perhaps finding a sustainable country, enough food, water and shelter for any African country [21]. Therefore, there is a possibility that the concept of sustainability may be a distraction or deception tactic that some countries suggest and use to reach their goals. Today, it can be said that globalization has removed relative boundaries on land, but this situation is getting more difficult to struggle to get what it deserves. In the northern hemisphere, giant countries are pushing the countries in the southern hemisphere and this situation is getting worse day by day. Namely, "When the people in China start to consume like in the USA, will the world's resources be enough for this?" comes to mind. A situation like this will not continue further. The countries that make up the rich club, if they do not learn to share the wealth today due to compulsory compromises from future welfare levels this can bring them to the brink of complete disaster. Therefore, these countries mentioned in the real sense of sustainable development target are in need.

The way to achieve sustainable development is through the reduction of waste and consumption, that is, the application of the formula $\mathrm{I}(\downarrow)=\mathrm{P}(\uparrow)+\mathrm{W}(\downarrow \downarrow)$. Because now, the world is working well above its bioproduction capacity. In other words, two worlds are enough to balance current consumption. It is also clear that the current situation is unsustainable, assuming that the level of welfare is equally distributed worldwide. Another remedy is to find a new planet and the world, which is livable and accessible. However, due to the very high escape energy, very little (1\%) of people can be sent even if all the energies in the world are used, even if Mars which is near us. Again, the solution comes to sustainable development. Either in real terms, sustainable development will be realized or situations of turmoil, war and anarchy will arise. This choice and its results will belong to human beings [22].

\subsubsection{Sustainability in the Turkish education system}

In short, when the Turkish Education system is examined; Turkey is still not possible to mentioned about an original national training program. Turkey, its own (culture, religion and race...) is obliged to develop a theory of learning and teaching. Current value of the education system and the 
judiciary, the teachings and philosophy of Turkey's own value judgments is limited to meet the teachings and philosophy. If it is desired to be expressed in another way existing education system remains stump for Turkey. So far, Turkey did not have an original training program. Only the programs were changed and modified due to the strain of time and needs of time. But the program is not still in Turkey's history, culture, region and found items belonging to the faith.

Sustainability is entering a new concept in Turkey in the new primary school curriculum. However, due to the situations mentioned above, this should be carefully considered and evaluated [23]. The concept of sustainability and related subjects are embedded in the curriculum of Science Course, Social Studies Course and Turkish Course. However, the 8th grade students' first encounter in the Science Course is the under the title of sustainable development which related to topics resources and recycling. The hours allocated for sustainable development were included in the program as six hours for the eighth grade [24]. When it is evaluated in terms of allocated lesson time and grade level, it is seen that the education given for sustainable development is limited. Instead, it is recommended that the principles, values and practices of sustainable development be implemented in sufficient teaching hours at all levels, starting from preschool.

\subsubsection{Sustainability in terms of various variables}

Variables such as culture, belief, race, gender and income, the media, academia and policy environments in which they are addressed, and the methods of sociology, psychology and scientific handling take the term "Sustainability" to more interesting dimensions. Firstly, the concept of sustainability can be viewed in terms of feminism. Hearing the word feminist at the first moment can cause anxiety in some people. But in today's masculine system, it will not hurt to approach something feminine. In fact, in the prevention of human and environmental disasters experienced in recent centuries, we need the feelings of mercy and sincere compassion and sincere mercy in women, especially in elderly conservative women. Age can be an important factor in humans. As people get older, they automatically see the world differently. Research can be done on life, world and sustainability issues. Otherwise, the issues may not be compatible with daily life. Middle-income and faithful people tend to protect and respect nature. The impact of race and culture on this concept is waiting to be discovered [25]. The media presents the issue in the context of fear and gifts. Political leaders can use sustainability as a tool to achieve their election goals [26]. Today, people are called homo economicus instead of homo sapiens. The economy comes to the forefront for the homo economicus. These concepts can be decisive for people. Real and reliable approaches come from academics and universities. However, most citizens cannot fully understand what academics are saying. Because, it is necessary to find new explanation techniques that contain understandable, reportable, sufficient and sustainable information without irritating the minds of the people.

Different disciplines include natural and humanities biology, chemistry, geography, economics and sociology etc. like all of them try to explain sustainability. When the concept of sustainability started to be expressed by scientists of biological origin, it was first considered as habitats and their protection. Chemistry reflects anthropocentric (human axis) effect with industry. In this respect, the biological and chemical perspective on the subject constitutes the discussion. Environmental engineering tries to unify the subject, while fields such as space science try to look at the subject from wide perspectives [27]. In addition, the concept of sustainability has mutual relations with concepts such as ecological citizenship, entrepreneurship, ecological footprint [28]. The individual and easily calculated ecological footprint measures the amount of soil required for the survival of the world and this index value is generally above 2. This means that you need more than one world to sustain modern life [29]. Although environmental citizenship and ecological citizenship, which are seen as equivalent to it, are similar, there are nuances with great results. Environmental citizenship gives the citizen responsibility in protecting the environment, while ecological citizenship regards the environment and other living creatures equally. Like the same person, nature must have its own rights [30]. Since we are all subsequent elements of this world, there should not be much difference between each other.

\subsection{Renewable Energy Sources}

The crisis of human communities on the planet has become acute both locally and globally. The reason for this crisis is that natural systems cannot meet human needs. Energy scarcity is the main source of conflicts that are spreading all over the world and increasingly continuing [31]. At this point, it comes to mind what kind of alternative energy sources should focus on for a sustainable energy future [32]. Otherwise, assuming that the world population is 8 billion in 2030, 2-3 times more energy will be consumed than current energy consumption [22]. Various reasons such as the increasing demand for energy, as well as providing energy security and sustainability, accelerate the search for alternative energy [33].

Sustainable energy and material supply are of primary importance for human civilization. Petroleum, coal and natural gas are the pillars of energy and material resources. Nuclear energy is their complement. Production, storage and transportation of sustainable energy can only be achieved by equal distribution of energy sources in various forms and phases. The balanced distribution of the energy cycle between these phases is sensitive to maintaining the natural 
cycle. In this way, human impact in nature can be mitigated. These conventional fossil sources are interestingly found in three phases of matter, solid (coal), liquid (oil) and gas (natural gas), and show a delicate balance. It is assumed that large amounts of various biomass residues have been converted into these resources by a spontaneous process in the Earth's crust. This is an adiabatic process where the temperature is constant and the pressure changes. But now renewable energy sources have gained great importance. Solar energy, wind energy and biomass energy are some of them. Material production from waste, energy recycling and regeneration are additional topics for renewable energy sources. Biomass use, which is one of the sources of renewable energy and materials, has two dimensions: (1) Energy and substance sources and (2) Clean environmental perspectives [33-35].

In this context, renewable energy sources are not only complementary to fossil sources but also an indication of the suitability of human behavior to nature. The popularity of renewable energy sources is gaining momentum day by day as it is more environmentally friendly than other energy sources [36]. At the same time, the fact that technologies related to renewable energy sources are new restricts their widespread use for now. Some governments have made laws to encourage the use of these energy sources until 2009. Currently, the ratio of renewable energy among energy sources for OECD countries is $5.2 \%$ on a country basis and $2.1 \%$ on a world basis [37]. Especially in developed countries, investment in these sectors is increasing rapidly [38].

All the same, renewable power plants have both positive and negative effects. For example, hydroelectric power plants have reduced the cost of electricity generation despite the construction cost of dams. It also had economic benefits such as irrigation, fishing and tourism. However, since electricity production depends on the amount of water collected, these studies can be counted as negative aspects of hydroelectric power plants, destroying habitats living below the water, historical and touristic places under the dams. Wind power plants are harmless to the environment during their construction and can be built in suitable places. However, the storage cost is very high.

As a separate carriage, nuclear power plants have high costs. But they reduce the electricity production cost considerably. Normally, the problem of storage of nuclear waste is harmless to the environment. However, the destructive effects of the accident that will take place in a nuclear power plant can be seen for decades. Nuclear centers do not cause air pollution and can make a positive contribution to the country's image [39-41].

Biomass, another renewable resource, is a by-product of photosynthesis and is basically similar to traditional energy sources. It is well known that its origin and biomass are the same as fossil fuels. Since the discovery of conventional energy sources, wood has been used for a long time as sustainable and renewable since its consumption is low. Wood is far from meeting the energy needed by the busy sectors of today and its use has been reduced due to many environmental factors. Also, its use is limited in some special areas such as decoration. All plant and animal residues other than wood can be named as biomass. There are many types of biomass compared to conventional energy sources. But they have similar contents. It mainly contains various proportions of cellulose, hemicellulose and lignin [42-44]. To make a small comparison, fossil fuel plants produce low cost electricity due to the abundant raw materials. However, our world is significantly polluted with air, water and soil pollution $[45,46]$. Because intensive use does not enable the removal of the impurities caused by photosynthesis and other natural cycles in the same time frame. Yet, whether it is edible energy or conventional sources of energy and materials, excessive and misuse has dangerous effects on the environment [47, 48]. It continues on nuclear ones in the most important and deep discussion [49]. These discussions started with Chernobyl and continued with Fukushima [50]. Society does not have sufficient information about power plants and especially nuclear energy. Today, preference should be given to renewable energy rather than fossil fuels and nuclear power plants [39, 51-58].

\subsection{Energy policies and problems}

Energy is a concept that concerns many fields from politics to academia, from science to media, it is also one of the most abstract concepts in science, education and daily life. Although we cannot see energy as an autonomous power, it is everywhere. Energy is simply defined as the ability to do business. Therefore, it is exposed indirectly. Energy cannot be stored as energy. Instead, energy always has matter and radiation forms ready for use. Burning, generating heat and moving pistons in car engines are examples of energy in gas, and synthesizing glucose through photosynthesis is an example of the energy of the sun that is released through electromagnetic waves. Therefore, the main subject is sustainable energy production, storage and transportation. People in today's postmodern society want to use energy comfortably whenever they want. However, this situation is far from being sustainable according to some estimates. Human beings will have to rethink whether they will continue to find habits, energy consumption changes and whether to continue to find alternative and sustainable energy sources or to consume non-renewable energy sources. Excitingly dangerous roads appear to humanity in all possible situations. Regardless of the way, finding solutions for energy problems of different shapes must be tried by people. This discussion is based on the interrelationships of energy, entropy, efficiency, economy, sociology, ecology, 
citizenship and entrepreneurship.

One of the main problems is the lack of communication between universities and government organizations. All governments keep their energy demands and resources secret. Because this information is strategic information and it cannot be spread through public awareness and even academic means. In this case, academicians' efforts are treated as an academic game. Academicians cannot concentrate on a clean environment perspective other than renewable energy studies and green energy studies. If we live in one and the same world, a group or a country should not be the sole authority over this world. In this case, it is difficult to predict whether renewable energy sources contribute to sustainable energy production throughout the world. One of the possible contributions to the solution of energy production is to use all kinds of waste. Carbon dioxide, used oils, plastics, biomass, glass, papers, debris wastes, metals and radioactive materials are some of these wastes. These wastes can be grouped according to their purposes such as dangerous, non-hazardous or solid, liquid, gas. These wastes present characteristic problems and also bring special uses. In this context, it constitutes a large work area.

Biomass and plastic wastes occur in large quantities from all walks of life. It can be estimated how much this could be. These wastes are commonly stored in open areas and together, as opposed to separate collection and accumulation efforts. In fact, biomass and plastics are polymer derivatives, although apparently different, polymers make up both natural and synthetic polymers. Biomass and biomass waste can result from human activity or what is called nature photosynthesis itself. A large amount of material called organic compounds is produced by photosynthesis. But basically, cellulosic materials outweigh organic materials such as starch and protein. Therefore, if the biomass is evaluated carefully, it may be a good alternative for energy sources. Synthetic polymers produced mainly from petroleum together with natural gas and coal are biomass and animal wastes belonging to prehistoric times when viewed from this pain. These petroleum, coal and natural gas resources are prepared very useful and stored for many years. Could this be possible again? comes to mind, but there is no evidence of an answer. Although there is no apparent evidence, biomass and plastics are mainly caused by photosynthesis. Therefore, these wastes can be converted into valuable products, i.e. fuels, by the final stage thermochemical methods in the final recycling, such as pyrolysis [59-61].

\subsection{Ecology, Economy, Energy}

Sustainability is achieved when the ecology economy and energy trio interact with society. These three concepts are called 3E. Ecology is sometimes referred to as nature. Emphasis is placed on the importance of nature and the elements that interact with nature. Living and inanimate beings interact in nature. As an example of flora and fauna, plants and animals are in constant interaction with other inanimate beings in nature. Energy is a vast, powerful and autonomous concept. The economy can sometimes be of prime importance. The interaction of these broad concepts is shown as intersecting circles. Sometimes the fourth circle representing society can be added to these three circles to achieve sustainable development.

Sustainability and renewable energy are in many ways intertwined. Ecology, economy and energy are indispensable concepts of our lives. These concepts affect each other in many ways in daily life. Every kind of energy conversion is accompanied by every process, from the smallest creatures and bodies to the largest systems and galaxies. Regardless of its source and type, the need for energy and therefore its resources are increasing day by day. This energy consumption in the society triggers many areas that constitute the economy. Especially the increase in unnecessary consumption increases production and consequently economies are growing. The increase in the production of consumer products and the effort to be more financially accessible reveal a perspective of tolerating some environmental problems in production. Tolerances in production arise especially in the way of ignoring the environmental damage to the environment. In addition, the amount of waste generated as a result of consumption affects the environment negatively [21].

When the figure above is examined, it is seen that ecology, economy and society are in constant interaction with each other. Sustainable development is a state of resilience without harming future generations. Different segments of society have different behaviors in waste. For example, some people send waste directly to the garbage while others reduce or recycle it. In this case, recycling should be added to the discussion. Because if the recycling process is not taken into consideration, environmental pollution will continue to be the biggest problem in the world and to be among the most important issue. Recycling is a broad term. It comes in third place after less consumption and reuse. If society recycles, the negative impact on ecology is reduced and an economy that produces environmentally friendly products emerges. For a livable world, society should reduce consumption and use. This reduces energy consumption and creates an environmentally friendly economy. Economic consumption is achieved by producing less by consuming less. At the same time, since there will be less production, less waste is generated and ecological benefit is provided. Similarly, it provides ecological benefit since it will not generate both economic and waste. If these situations are combined with the other form, it turns out what should be done for a habitable environment. 

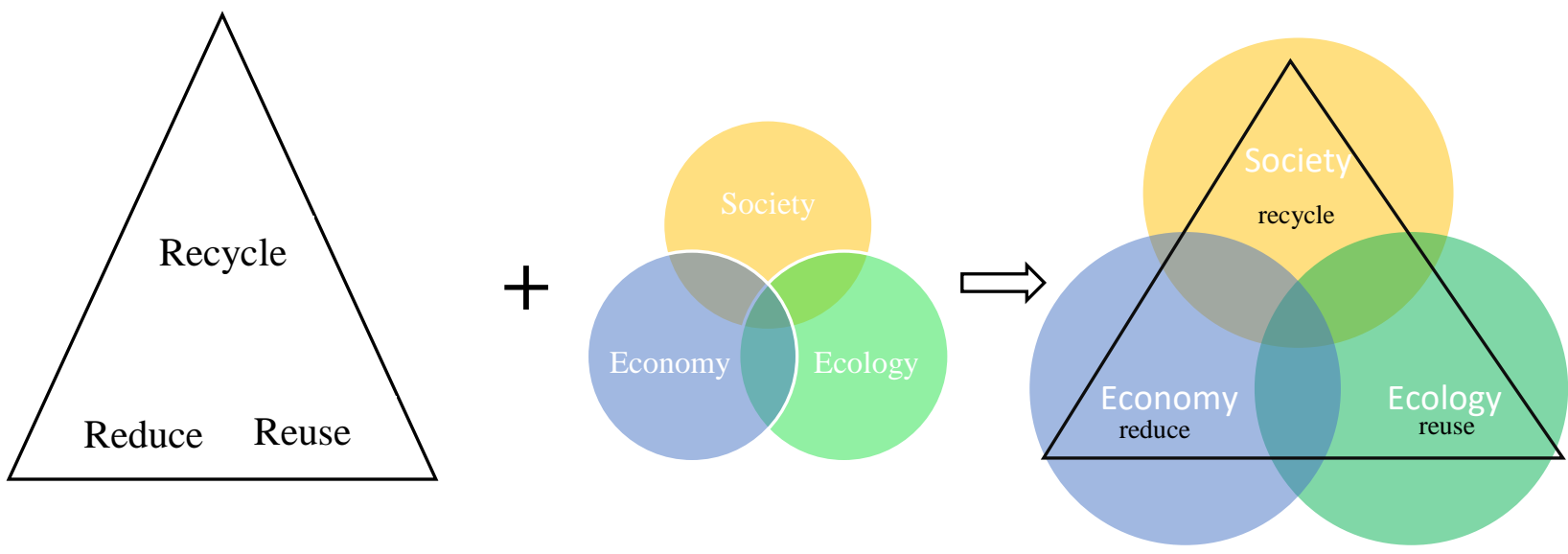

Fig. 3. Economy, Ecology and Society Relationship

\section{Conclusion and Recommendations}

While the basic problems encountered with the accumulation of knowledge of humanity in the globalizing world should be facilitated, unfortunately it has become more grippy. Today, economic development is not evenly distributed around the world. In addition, the gap between the richest and the poorest is widening. Now the best riches are earning times and times more than the lowest ones. In addition, the northern hemisphere consumes overwhelmingly more than that of the south. In this problem, it focuses very painfully on the maintenance of life, human life and generation that plants and animals can do on their own. If it cannot find a new life and production style, this does not seem sustainable.

The increase in population and consumption is therefore one of the most fundamental issues in the world. In general, this issue is related to the economy. Therefore, today, the human is called Homo Economicus. Therefore, Money is first and foremost the main goal in people's view. Perception of the person may be affected by economic profit in the decision phase. This situation comes after the need of the society and the protection of the environment. Technological developments also support production. At this point, the recycling process and environmental protection should be reconsidered. Today, environmental pollution reaches interstellar dimension. Wastes accumulated during production and consumption are tried to be thrown into space. It is not known what kind of disaster awaits as a result of the wastes thrown into space back to where we live. In order to minimize the harm of individuals to nature, individuals should have sustainable development awareness and put this awareness in their minds. This happens only through education. Education can be provided to individuals with sustainable development ability. With the effect of education, the rate of change in nature conditions may decrease, otherwise conditions such as air temperature, sea temperature or air pollution will worsen day by day. With increasing education knowledge, financial investments turn into social investments. The definition of social investments aims to reduce low emissions and waste for global warming, pollution. For example; an investor has an environmentalist realism capability that primarily directs financial decisions to social investment. In this way, education makes generations more sensitive to nature and treats nature in behavior.

The sustainable development model remains the best conceptual framework ever developed. Continuity is essential, albeit a little. The solution lies at the intersection of ecology, economy and energy circle trilogy. Increasing this overlap and overlap rate and keeping it at a certain point can be considered as sustainable development. Meanwhile, the concept of equality, which has the potential to be one of the 3 Es, should not be ignored. It turns out that all individuals consume less for sustainable life, and they are happy when doing so. Because there is a lifestyle form that is conscious of nature in the existence of these individuals. These individuals mostly reflect the attitudes and behaviors of older conservative women. Then, these individuals who make up the society become the least damaging to the nature by using renewable energy sources. In this way, it contributes to the betterment of the world.

Interestingly, chemistry and commerce are at the heart of sustainable development. Chemistry is concerned with the transformation of these products into the economy, while examining the compatibility of objects with each other. Therefore, small advances in chemistry and technologies constitute various steps in solving basic problems. These are named as the production of various products equivalent to oil, coal and natural gas with various thermochemical conversion techniques from wastes. Meanwhile, while the environment is protected, human motivation is provided politically.

In addition, individuals will change their behavior through the definition of environmental law regulations, the changed view of environmental education and the perception of profit triggered by effective carbon markets. In this way, 
individuals become more protective and careful to balance the natural conditions. All their behaviors include careful use of natural resources. These actions take back the environment and reduce the effects of global warming and pollution. To ensure this obligation, the level of ecological citizenship of individuals in the society should be increased, that is, sustainable development should be realized. The last word is that common actions can make a big difference to save the planet.

\section{$\underline{\text { ORCID }}$ \\ Fatih Şeker \\ Çağrı Avan \\ 0000-0003-0427-9208 \\ Bahattin Aydinlı \\ $0000-0002-4068-7631$ \\ 0000-0002-6525-4162}

\section{References}

[1] Ateş, H. \& Gül, K.S. (2018). Investigating of preservice science teachers' beliefs on education for sustainable development and sustainable behaviors. International Electronic Journal of Environmental Education, 8(2), 105-122.

[2] Erciş, A., \& Türk, B. (2018). In the frame of ethics consumption, consumer and the environment: the moderator role of ecoliteracy. Journal of Cukurova University Faculty of Economics and Administrative Sciences, 20(2), 1-24.

[3] Prabawani, B., Hanika, I.M., Pradhanawati, A., \& Budiatmo, A. (2017). Primary schools eco-friendly education in the frame of education for sustainable development. International Journal of Environmental \& Science Education, 12(4), 607-616.

[4] Bjerke, T. \& Kaltenborn, B.P. (1999). The relationship of ecocentric and anthropocentric motives to attitudes toward large carnivores. Journal of Environmental Psychology, 19, 415-421.

[5] Hoffman, A. J., \& Sandelands, L. E. (2005). Getting Right with Nature. Organization \& Environment, 18(2), 141-162. doi:10.1177/1086026605276197.

[6] Mebratu, D. (1998). Sustainability and sustainable development: historical and conceptual review. Environmental impact assessment review, 18(6), 493-520.

[7] Gupta, J., \& Vegelin, C. (2016). Sustainable development goals and inclusive development. International Environmental Agreements: Politics, Law and Economics, 16, 433-448. DOI 10.1007/s10784016-9323-z

[8] Arya, D., \& Maul, A. (2016). The building of knowledge, language, and decision-making about climate change science: A cross-national program for secondary students. International Journal of Science Education, 38(6), 885-904.
[9] Kurniawan, R. \& Managi, S. (2017). Sustainable development and performance measurement: Global productivity decomposition. Sustainable Development, 654, 639-654. https://doi.org/10.1002/sd.1684

[10] Glasson, G. E., Mhango, N., Phiri, A., \& Lanier, M. (2009). Sustainability science education in Africa: Negotiating indigenous ways of living with nature in the third space. International Journal of Science Education, 32(1), 125-141.

[11] Feinstein N. W., \& Kirchgasler, K. L. (2014). Sustainability in science education? How the next generation science standards approach sustainability, and why it matters. Science Education, 99(1), 121-144. doi:10.1002/sce. 21137

[12] Miller, T. R. (2013). Constructing sustainability science: Emerging perspectives and research trajectories. Sustainability Science, 8(2), 279-293.

[13] Sakschewski, M., Eggert, S., Schneider, S., \& Bögeholz, S. (2014). Students' socioscientific reasoning and decision-making on energy-related issues-development of a measurement instrument, International Journal of Science Education, 36:14, 2291-2313, DOI: 10.1080/09500693.2014.920550.

[14] Leiserowitz, Anthony A., Kates, Robert W., \& Parris, Thomas M. (2006). Sustainability values, attitudes, and behaviors: A review of multinational and global trends. Annual Review of Environment and Resources. Annual Reviews, Palo Alto, Ca, USA.

[15] Van Kerkhoff, L. \& Lebel, L. (2006). Linking knowledge and action for sustainable development Annual Review of Environment and Resources. Annual Reviews, Palo Alto, Ca, USA.

[16] Şeker, F., \& Aydinlı, B. (2016). The didactic of sustainable development terms in science education. European Journal of Social Sciences Education and Research. 6(2), 123-132.

[17] Tytler, R. (2012). Socio-Scientific Issues, Sustainability and Science Education. Research in Science Education, 42(1), 155163. doi:10.1007/s11165-011-9262-1

[18] Jesus, M. D., Foti, R., Rinaldo, A., \& Rodriguez-Iturbe, I. (2012). Maximum entropy production, carbon assimilation, and the spatial organization of vegetation in river basins. PNAS, 109(51), 20837-20841.

[19] Juretic', D., \& Županovic', P., (2003). Photosynthetic models with maximum entropy production in irreversible charge transfer steps. Computational Biology and Chemistry, 27, 541-553.

[20] Johannesson, I., Noradahl, K., Oskarsdottir, G., Palsdottir, A., \& Petursdottir, B. (2011). Curriculum analysis and education for sustainable development in Iceland. Environmental Education Research, 17(3), 375-391. 
[21] Fyfe, WS. (2002). Toward sustainable cities: priorities in economics, ecology and education. Advances In Architecture Series, 14, Segovia, Spain.

[22] Blinc, R., Zidansek, A., \& Slaus, I. (2007). Sustainable development and global security. Energy, 32, 883-890.

[23] Calık, M. \& Eames, C. (2012). The significance of a national context: A comparison of environmental education in Turkey and New Zealand. Asia-Pacific Education Researcher, 21(3), 423-433.

[24] Ministry of National Education (MoNE) (2018). [Elementary school science curriculum (Grades for 38)]. $\quad$ Retrieved from http://mufredat.meb.gov.tr/Dosyalar/201812312311937FEN\%20B\%C4\%B0L\%C4\%B0MLER\%C4\%B0\%20\%C3\% 96\%C4\%9ERET\%C4\%B0M\%20PROGRAMI2018.pdf

[25] Benvenisti, E. (2008). Asian traditions and contemporary international law on the management of natural resources. Chinese Journal of International Law, 7(2), 273-283.

[26] Luke, T. W. (2008). The politics of true convenience or inconvenient truth: struggles over how to sustain capitalism, democracy, and ecology in the 21 st century. Environment and Planning, Oxford, ENGLAND.

[27] Miller, T.R., Wiek, A., Sarewitz, D. et al. (2014). The future of sustainability science: a solutions-oriented research agenda. Sustainability Science, 9, 239-246.

[28] Lourenco, F., Jones, O., \& Jayawarna, D. (2013). Promoting sustainable development: The role of entrepreneurship education. International Small Business Journal, 31, 8, (841-865).

[29] Buğra, A. (2007). Poverty and citizenship: An overview of the social-policy environment in republican Turkey. International Journal of Middle East Studies, 39(1), 3352.

[30] Dobson, A. (2003). Citizenship and the environment. Oxford University Press.

[31] Colucci-Gray, L., Perazzone, A., Dodman, M., \& Camino, E. (2012). Science education for sustainability, epistemological reflections and educational practices: from natural sciences to transdisciplinarity. Cultural Studies of Science Education, 8(1), 127-183. doi:10.1007/s11422-012-9405-3.

[32] İşeri, E. \& Özen, C. (2012). Sustainability and Turkey's nuclear energy policy. İ.Ü. Siyasal Istanbul University Journal of Political Sciences, 47, 161-180.

[33] Aydın, F. \& Çalışkan, S. (2020). Evaluation of biodiesel produced from tea seed oil in terms of fatty acid components. International Journal of Energy Applications and Technologies, 7(1), 13-19.

[34] De Wit, M., Londo, M., \& Faaij, A. (2011). Productivity developments in European agriculture: Relations to and opportunities for biomass production. Renewable and Sustainable Energy Review, 15, 2397-2412.
[35] Ekpenia L, E. N., Benyounisa K.Y., Nkem-Ekpenib F, Stokesa, J., \& Olabic, A.G. (2014) Energy diversity through renewable energy source (RES) - A case study of biomass. Energy Procedia, 61, 1740-1747.

[36] Dincer, I. (2000). Renewable energy and sustainable development a crucial review. Renewable and Sustainable Energy Reviews, 4, 157-175.

[37] OECD. (2010). Public attitudes to nuclear power, nuclear energy agency organization for economic cooperation and development. https://www.oecdnea.org/ndd/reports/2010/nea6859-publicattitudes.pdf. (accessed 07.06.2015).

[38] Kum, H. (2009). Renewable energy sources: recent developments and policies in world markets., Journal of Erciyes University Faculty of Economics and Administrative Sciences, 33, 207-223.

[39] Kim, M. (2013). Risk communication about nuclear power in Korea: one-year descriptive analysis on twitter. Science Education International, 24 (3), 324343.

[40] URL 1. http://www.epa.gov/cleanenergy/energy-andyou/affect/nuclear.html. (accessed 15.06.2015).

[41] URL 2. http://www.physics.isu.edu/radinf/np-risk.htm. (accessed 18.06.2015).

[42] Kim, S.W. (2015) Prediction of product distribution in fine biomass pyrolysis in fluidized beds based on proximate analysis. Bioresource Technology, 175, 275283.

[43] Topçu, E., \& Aydınlı, B. (2016). The Determination of Cognitive Structure of Candidate Teachers About Energy Centrals. International Electronic Journal of Environmental Education, 6(2).

[44] Yilmaz, A., \& Bayrakçeken, S. (2015). Determining of the prospective teachers' understadings of electrochemistry. Procedia-Social and Behavioral Sciences, 174, 2831-2838.

[45] Coşkun, M. \& Akbaş, V. (2017). From black sea coastal to inland: Climatic parameters of kastamonu surroundings. The Journal of Social Science, 4(11), 4686.

[46] Goncaloğlu, B.İ., Ertürk, F., \& Ekdal, A. (2000). Comparison of thermal power plants and nuclear power plants in terms of environmental impact assessment. Journal pf Ecology Environment. 9(34) 9-14.

[47] Ertürk, F., Akkoyunlu A., \& Varınca, K.B. (2006). Energy production and environmental effects fossil hydraulic renewable nuclear. TASAM Strategic Report. No: 14.

[48] Ürker, O. \& Çobanoğlu, N. (2012). In Turkey, the status of the hydroelectric power plants and be evaluated in the context of environmental policy. Journal of Ankara University Institute of Social Sciences, 3(2), 65-88. 
[49] Altın, V. (2004). Nuclear energy to new horizons. Science and Technique. TÜBITTAK.

[50] Stoutenborough, J.W., Sturgess S.G. \& Vedlitz, A. (2013). Knowledge, Risk, and Policy Support: Public Perceptions of Nuclear Power. Energy Policy, 62, 176184.

[51] Lee, C., Hu, S., \& Chang, W. P. (1999). A study on risk perception toward nuclear power operation in Taiwan. Institute of Public Health, and Institute of Environmental Health Sciences, National Yang-Ming University, Taiwan.

[52] Aydın, F., Coskun, M., Kaya, H., \& Erdönmez, İ. (2011). Gifted students' attitudes towards environment: a case study from Turkey. African Journal of Agricultural Research, 6(7), 1876-1883.

[53] Lee, L. \& Yang, H. (2013). Technology teachers' attitudes toward nuclear energy and their implications for technology education. Online Submission, http://files.eric.ed.gov/fulltext/ED545402.pdf. (accessed 06.05.2015).

[54] De Groot, J.M., Steg, L., \& Poortinga, W. (2013). Values, perceived risks and benefits and acceptability of nuclear energy; Risk Analysis, 33(2), 307- 317.

[55] Kenar, İ. (2013), Nuclear energy reality in Turkey and the attitude of the science teachers towards the issue. Kamla-Raj. Anthropologist, 16 (1-2), 153-165.

[56] Arikawa, H., Cao, Y., \& Matsumoto, S. (2014). Attitudes toward nuclear power and energy-saving behavior among Japanese households. Energy Research \& Social Science, 2, 12-20.

[57] Haşıloğlu, M. A. (2014). The examining of prospective teachers' views about renewable and non-renewable energy sources: a case study of Turkey. Academic Journals. 9 (13) 411-416.

[58] Charısiou N.D. \& Goula M.A. (2014). Attitudes of Greek university students towards energy and the environment. Global Nest Journal, 16(5), 856- 865.

[59] Karaci, A., Caglar, A., Aydinli, B., \& Pekol, S. (2016). The pyrolysis process verification of hydrogen rich gas $(\mathrm{H}-\mathrm{rG})$ production by artificial neural network (ANN). International journal of hydrogen energy, 41(8), 4570-4578.

[60] Aydinli, B., Avan, Ç., Pekol, S., \& Caglar, A. (2016). The ecological awareness imparted by civil foundation for sustainable environment. 10th International symposium on agriculture and the environment, (AgroEnviron 2016), May 23-27, 2016.

[61] Caglar, A. \& Aydinli, B. (2009). Isothermal copyrolysis of hazelnut shell and ultra-high molecular weight polyethylene: The effect of temperature and composition on the amount of pyrolysis products. Journal of Analytical and Applied Pyrolysis, 86(2), 304-309. 